\title{
Efficacy of Conventional Tree Stabilization Systems and their Effect on Short-Term Tree Development
}

\author{
Alexis A. Alvey, P. Eric Wiseman, and Brian Kane
}

\begin{abstract}
We evaluated three conventional tree stabilization systems (staking, guying, and root ball anchoring) on $6.4 \mathrm{~cm}$ (2.5 in) caliper field-grown, balled and burlapped white ash (Fraxinus americana L. 'Autumn Purple'). At five weeks and at seven months after planting, performance of the stabilization systems was evaluated under ambient wind conditions as well as wind-simulating pull tests. Nonstabilized ash trees remained upright during both the 5-week and 7-month studies despite occasionally substantial wind gusts. From the pull tests, the study found the stabilization systems performed equally well and that even nonstabilized ash trees were tolerant of moderate to heavy wind loads. Stabilization systems differed in the maximum force they endured before component failure. The guying system withstood forces 1.7 to 2.5 times greater than the root ball anchoring and staking systems, respectively. Stabilization system components were very durable during the first growing season and did not substantially impact tree height growth, shoot elongation, root diameter, root length, or root mass seven months after planting. After one growing season, both nonstabilized and previously stabilized trees remained upright until unrealistically large loads were applied. Practical implications for landscape tree management are discussed.

Key Words. Anchoring; Guying; Planting; Pull Tests; Staking; Tree Stabilization; Tree Support; Wind.
\end{abstract}

Tree stabilization systems (TSS) are commonly installed on transplanted trees to provide (1) anchorage and aid root establishment, (2) trunk support for trees that cannot stand upright on their own, and (3) protection from landscaping equipment, automobiles, and vandals (Leiser and Kemper 1968; Harris 1984; Smiley et al. 2003; Appleton et al. 2008). The first application is the most common; recently transplanted landscape trees may be prone to destabilization from root ball shifting and inadequate root anchorage, which can require costly follow-up care to reposition or replace the tree (Appleton et al. 2008). It is believed that excessive movement of the root system breaks new roots that have extended into the backfill soil, possibly inhibiting tree establishment and growth (Appleton and Beatty 2004).

There are three conventional TSS configurations: staking, guying, and root ball anchoring. Staking entails one to four tall stakes (one-third to two-third total tree height) positioned around the tree with a horizontally-oriented strap secured between the top of each stake and the trunk. Guying entails one to four short soil anchors positioned around the tree with an angled guyline secured between each anchor and the trunk. Root ball anchoring entails immobilizing the root ball with stakes and/or straps placed over, around, or through the root ball and beneath the soil surface. These TSS configurations can be fabricated from general hardware supplies or purchased as proprietary systems. A recent survey identified no less than a dozen commercial TSS products (Appleton et al. 2008).

While there are compelling reasons to use TSS on landscape trees, there are also numerous disadvantages of tree stabilization (e.g., Appleton et al. 2008). Of greatest concern to arborists are the cost of TSS and their potentially negative impact on tree health and development. The costs to purchase, install, and maintain a TSS can add considerably to the total establishment cost of a landscape tree. In a recent survey of 250 landscape practitioners, cost and ease of removal ranked highly among the most important shortterm and long-term TSS selection criteria (Appleton et al. 2008).

TSS components that attach to trunks or branches can cause abrasion and girdling (Leiser and Kemper 1968; Harris and Hamilton 1969). In Boston, MA, U.S. staking caused more damage to trees than automobiles or vandalism (Foster and Blaine 1978). Nearly three-fourths of surveyed practitioners had observed tree damage (usually trunk girdling) from TSS not removed in a timely manner (Appleton et al. 2008). Aboveground TSS can also predispose trees to trunk breakage (Leiser and Kemper 1973); staked trees have been observed with their trunks broken at the point of attachment (Patch 1987). Leiser and Kemper (1968) estimated that stakes attached above two-thirds of the total tree height caused trunk stress three to five times greater than on nonstaked trees.

Aboveground TSS can also alter trunk and root development, which may have implications for long-term structural integrity. Holbrook and Putz (1989) found that four-year-old sweetgum (Liquidambar styraciflua L.) saplings that had been guyed for two years were taller and had thinner, less-tapered stems than nonstabilized saplings. Neel (1967) applied various staking configurations to one-year-old, containerized sweetgum, Japanese zelkova (Zelkova serrata Thunb.), mountain birch (Betula pubescens Ehrh.), and Chinese pistache (Pistacia chinensis Bunge.). Staking decreased the rate of diameter growth, increased height growth, inhibited the formation of reaction wood, and decreased trunk taper progressively as the degree of tree immobilization increased.

After guying young Scots pine (Pinus sylvestris L.) for two years, Fayle (1976) found that roots originating from the trunk-root junction of guyed trees had grown in width only about half that of nonstabilized trees. Fayle also found that compression wood was present more frequently and in greater quantities on the exposed, horizontal roots of nonstabilized 
trees. Sitka spruce (Picea sitchensis Bong.) stabilized with a single stake had significantly less dry root mass than nonstabilized trees (Mayhead and Jenkins 1992). In addition, the area, depth, and volume of soil occupied by excavated roots $\geq 0.2$ $\mathrm{cm}(0.08 \mathrm{in})$ in diameter were significantly less for staked trees.

Given the potential disadvantages of TSS, there is a clear need to better understand TSS efficacy so that their use can be properly justified and prescribed. Of particular interest is the ability of various TSS configurations/products to prevent tree destabilization, which has received limited attention from researchers. Whalley (1982) studied the stability of container-grown Leyland cypress (X Cupressocyparis leylandii Dallim. \& A.B. Jackson) using three different staking materials. The trees were transplanted and then staked for three years. In the two years following stake removal, $92 \%$ of trees that had been staked with a rigid metal pole blew over, $10 \%$ of trees staked with a medium-weight bamboo stake blew over, $2 \%$ of trees staked with a lightweight cane stake blew over, and zero of the nonstaked trees blew over. Appleton and Beatty (2004) tested twelve different above and belowground TSS on field-grown, $5 \mathrm{~cm}$ (2 in) diameter Bradford pears (Pyrus calleryana Decne. 'Bradford') transplanted to an experimental field site. No trees, including nonstabilized trees, were leaning or damaged one year after installation, despite a category two hurricane passing through the area six months after planting. In contrast, they observed that all nonstabilized Chinese elm (Ulmus parvifolia Jacq.) evaluated on a nearby study site were significantly destabilized after the hurricane. Elms with either aboveground or belowground TSS had insignificant leans both after the hurricane and one year after transplant.

Limited inferences can be made from observational studies of TSS performance under prevailing weather conditions. Tree pulling tests are a commonly accepted approach to simulating wind forces (Peltola et al. 2000) and allow TSS to be evaluated under controlled experimental conditions. Eckstein and Gilman (2008) conducted pull tests on newly planted $7 \mathrm{~cm}$ (2.8 in) caliper, container-grown live oak (Quercus virginiana Mill.) to simulate wind loading effects on nine commonly used TSS. In a saturated sandy soil, six out of nine TSS required more force to destabilize than nonstabilized controls. The study did not calibrate destabilization forces with wind speeds; therefore, it was not possible to relate TSS performance to landscape wind conditions.

The current study evaluated the performance of three conventional TSS (staking, guying, and root ball anchoring) that are commonly used on recently transplanted landscape trees. The research objectives were to investigate:

1. TSS effects on tree stability soon after planting and after one growing season

2. The relative strength of each TSS

3. TSS effects on short-term tree growth and development

4. TSS material costs and installation time

\section{METHODS}

\section{Study Site and Experimental Trees}

This research project had three components: a wind load experiment, a short-term TSS experiment, and a long-term TSS experiment. The experiments were conducted at the Virginia Tech Urban Horticulture Center in Blacksburg, VA, U.S. (USDA Hardiness Zone 6a) from April to December 2006. The soil at the Center was Groseclose silt loam (clayey, mixed, mesic Typic Hapludult). The average soil bulk density measured within the experimental plots prior to tree planting was $1.42 \mathrm{~g} / \mathrm{cm}^{3}(\mathrm{SE}=0.01)$ at $5.0-7.5 \mathrm{~cm}$ (2-3 in) depth. During the May-December study period, maximum daily wind speed at the site averaged $7 \mathrm{~m} / \mathrm{s}(15 \mathrm{mph})$. In April 2006, 54 field grown, balled and burlapped white ash (Fraxinus americana L. 'Autumn Purple') were acquired from a local wholesale nursery. Six trees were randomly selected from the group for the wind load experiment. The remaining 48 trees were assigned to the TSS experiments and their physical dimensions were measured prior to planting (Table 1). Trunk taper $(\mathrm{t})$ was calculated as

[1] $\quad t=\left(D_{B}-D_{T}\right) \div L$,

where $D_{B}$ is the trunk diameter measured $15 \mathrm{~cm}(6 \mathrm{in})$ above the root flare, $\mathrm{D}_{\mathrm{T}}$ is the trunk diameter measured $15 \mathrm{~cm}$ below the lowest scaffold branch, and $\mathrm{L}$ is the distance between them.

\section{TSS Experiment Installation}

The long-term and short-term TSS experiments were installed in May 2006. For each experiment, 24 trees were planted in $3 \mathrm{~m}$ (10 $\mathrm{ft}$ ) wide rows in a staggered arrangement with $2.1 \mathrm{~m}(7 \mathrm{ft})$ between each tree. Planting holes were dug with a $61 \mathrm{~cm}$ (24 in) diameter tractor-mounted auger to a depth of $45 \mathrm{~cm}$ (18 in) and then widened to $107 \mathrm{~cm}$ (42 in) using a shovel. Trees were placed in the center of the planting holes and their depth was adjusted such that the root flare was even with the soil grade. Wire baskets and burlap were removed from the top third of each root ball. Backfill soil was placed around each root ball, uniformly compacted, and watered thoroughly. Planting rows were mulched with fresh wood chips and irrigated when rainfall was less than $2.5 \mathrm{~cm}$ (1 in) per week.

Immediately after planting, each tree was randomly assigned one of four stabilization treatments: staking, guying, root ball anchoring, or nonstabilized (control). There were six replications of each treatment in each experiment. All systems were constructed with untreated wooden components, and $1.3 \mathrm{~cm}(0.5$ in) polypropylene strapping (ArborTie ${ }^{\circ}$, Deep Root Partners L.P., San Francisco, CA) was used for guylines and stake straps (Figure 1).

For the staking system, three $5 \mathrm{~cm} \times 5 \mathrm{~cm} \times 183 \mathrm{~cm}(2$ in $\times$ 2 in $\times 72$ in) stakes were driven $61 \mathrm{~cm}$ vertically into the soil 76 $\mathrm{cm}$ (30 in) equidistant from the trunk. A strap was attached to the top of each stake with a clove hitch backed by a half hitch and secured to the trunk with a bowline. For the guying system,

Table 1. Physical dimensions of field-grown, balled and burlapped white ash (Fraxinus americana L. 'Autumn Purple') used in tree stabilization system experiments $(n=48)$. Measurements taken at planting.

\begin{tabular}{ccccc}
\hline $\begin{array}{c}\text { Trunk caliper } \\
(\mathrm{cm})\end{array}$ & $\begin{array}{c}\text { Trunk Taper } \\
(\mathrm{mm} / \mathrm{m})\end{array}$ & $\begin{array}{c}\text { Tree height } \\
(\mathrm{m})\end{array}$ & $\begin{array}{c}\text { Crown diameter } \\
(\mathrm{m})\end{array}$ & $\begin{array}{c}\text { Root ball diameter } \\
(\mathrm{cm})\end{array}$ \\
$6.04(0.04)$ & $12.40(0.39)$ & $4.80(0.06)$ & $1.74(0.06)$ & $\begin{array}{c}\text { Whole tree mass } \\
(\mathrm{kg})\end{array}$ \\
\hline
\end{tabular}




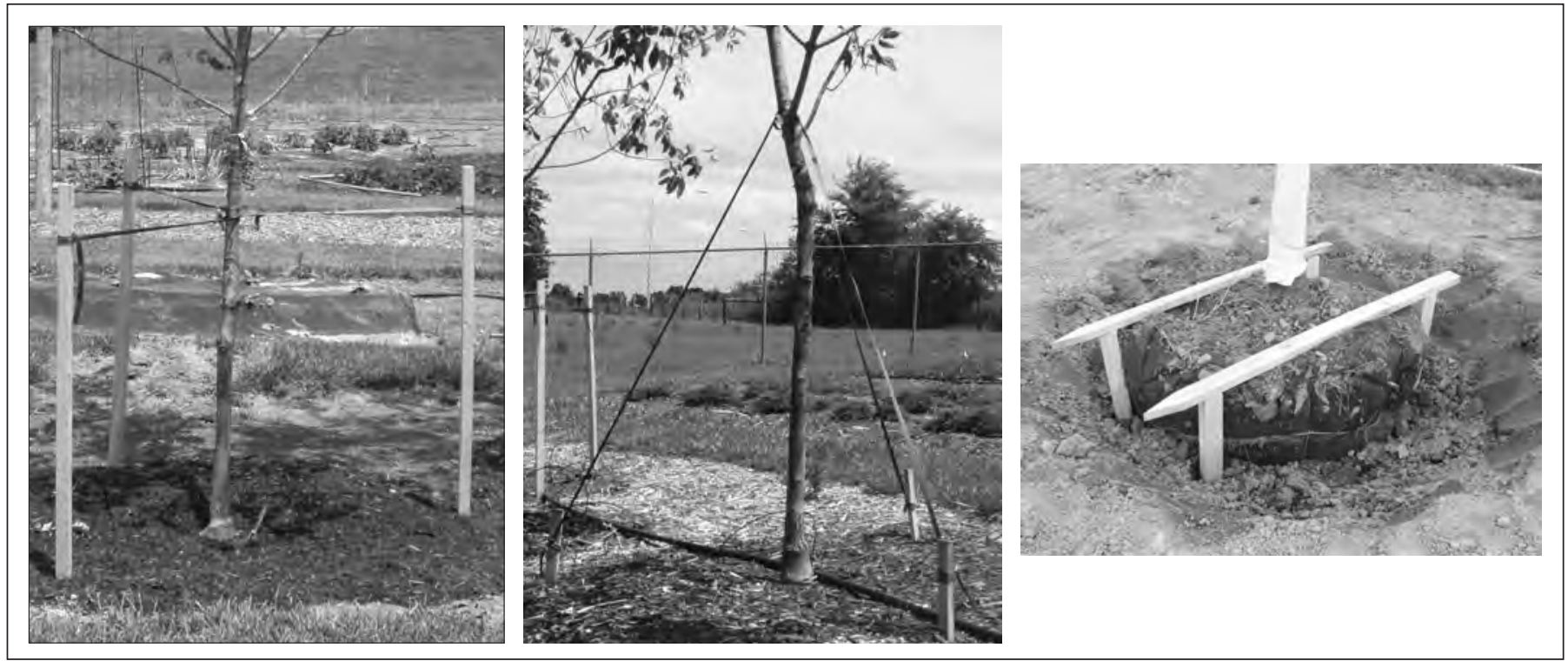

Figure 1. Tree stabilization systems evaluated on field-grown, balled and burlapped white ash (Fraxinus americana L. 'Autumn Purple'). From left to right, staking, guying, and root ball anchoring.

three $5 \mathrm{~cm} \times 5 \mathrm{~cm} \times 91 \mathrm{~cm}(2$ in $\times 2$ in $\times 36$ in $)$ anchors were driven $61 \mathrm{~cm}$ vertically into the soil $76 \mathrm{~cm}$ equidistant from the trunk. A strap was attached to the base of each anchor with a clove hitch backed by a half hitch and secured around the trunk and over the lowest scaffold branch with a bowline. For the root ball anchoring system, four $5 \mathrm{~cm} \times 5 \mathrm{~cm} \times 76 \mathrm{~cm}(2$ in $\times 2$ in $\times 30$ in) anchors were placed snug against the root ball on four corners and driven vertically into the soil until the top of the anchors were flush with the top of the root ball. Two $2.5 \mathrm{~cm} \times 5$ $\mathrm{cm} \times 91 \mathrm{~cm}(1$ in $\times 2$ in $\times 30$ in $)$ horizontal braces were then placed on top of each pair of vertical anchors and secured across the root ball using four $5 \mathrm{~cm}$ ( 2 in) \#10 wood screws. Root ball anchoring was installed prior to backfilling the planting hole.

\section{Wind Load Experiment}

To determine appropriate wind-simulating forces for the TSS experiments, wind-induced bending moments were measured for a sub-sample of six ash trees using the method of Smiley and Kane (2006). Each tree was severed from its root ball just above the flare and secured in a steel sled mounted in the rear of a pickup truck (Figure 2). A prusik cord was tied around the trunk at a height of $83.8 \mathrm{~cm}(2.75 \mathrm{ft})$ and attached to a $1.8 \mathrm{~m}(6 \mathrm{ft}) \mathrm{sec}-$ tion of $0.6 \mathrm{~cm}(0.25 \mathrm{in})$ extra-high-strength steel cable using a steel carabiner and a microascender. The horizontally-oriented cable was attached to a $2268 \mathrm{~kg}$ capacity Dillon ED Junior dynamometer (Weigh-Tronix Inc., Fairmont, MN), which was then secured to the front rack of the sled. The truck was then driven on a straight, nearly level course from 0 to $24.5 \mathrm{~m} / \mathrm{s}$ (0 to $55 \mathrm{mph}$ ). As the truck was driven, a passenger recorded the force measured by the dynamometer at $7,11,16,20$, and $25 \mathrm{~m} / \mathrm{s}(15,25,35,45$, and $55 \mathrm{mph}$ ). For each tree, two runs were made in opposite directions to minimize the effect of directional winds and the force values were averaged for each speed interval. This procedure introduces a component of force due to vehicle acceleration, but Kane et al. (2008) estimated it to be less than $2 \%$ of actual drag. To calculate wind-induced bending moments, force values were multiplied by the dynamometer attachment height on the trees.

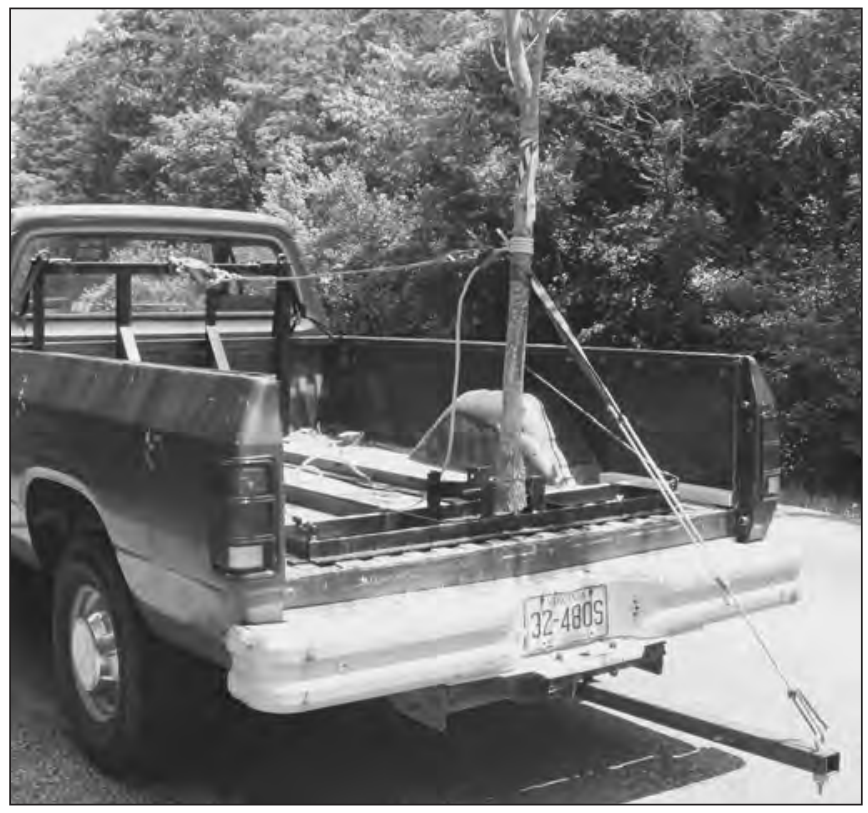

Figure 2. Truck-mounted tree sled used for measuring windinduced bending moment of white ash (Fraxinus americana $\mathrm{L}$. 'Autumn Purple') from 0 to $24.5 \mathrm{~m} / \mathrm{s}$ (0 to $55 \mathrm{mph}$ ).

\section{Tree Pulling Procedure}

Trees in the short-term experiment were pulled in June 2006, five weeks after planting, to assess TSS performance before roots had substantially grown out of the root ball. Trees in the long-term TSS experiment were pulled in December 2006, seven months after planting, to assess TSS impact on tree development and stability. Volumetric soil moisture of the backfill soil in planting holes was $29.6 \%(\mathrm{SE}=0.6)$ and $27.6 \%(\mathrm{SE}=0.4)$ when trees were pulled during the short-term and long-term experiments, respectively. The same pulling procedure was used in both experiments. A 12-volt winch (XD 9000i, Warn Industries, Inc., Clackamas, OR) was bolted to the bucket of a skid-steer loader 


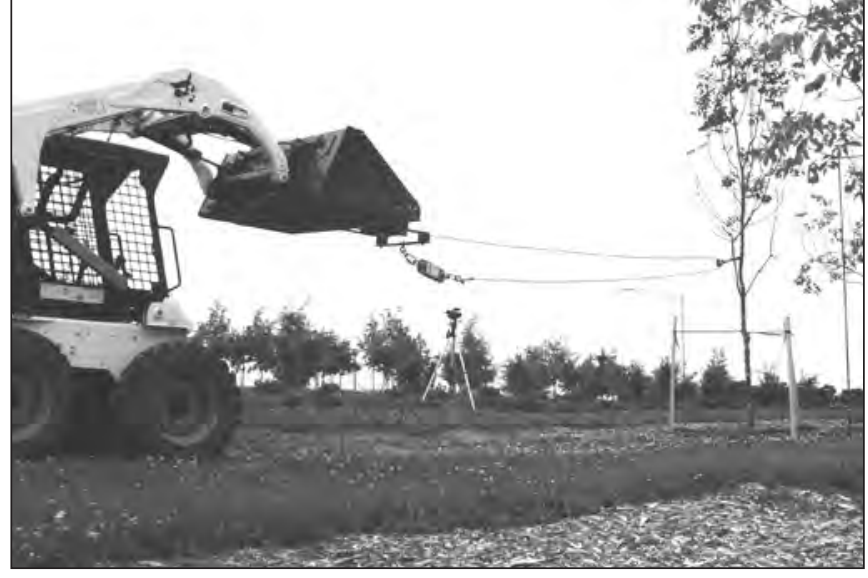

Figure 3. Configuration of pulling equipment and dynamometer used to evaluate tree stabilization systems (staking shown) on field-grown, balled and burlapped white ash (Fraxinus americana L. 'Autumn Purple').

(Bobcat ${ }^{\circledR}$ S185, Bobcat Co., Gwinner, ND), which was posi-

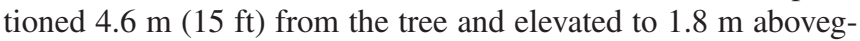
round. The winch cable was passed through a pulley attached to the tree $1.8 \mathrm{~m}$ aboveground and connected to the dynamometer, which was secured to the winch-mounting bracket (Figure 3).

Before pulling the trees, trunk orientation was measured both parallel to and normal to the direction of the applied force at $76 \mathrm{~cm}$ above the ground with an angle gauge (Johnson 700 Magnetic Angle Locator, Johnson Level \& Tool Mfg. Co., Mequon, WI). All trees were pulled parallel to the planting row in a single direction; Eckstein and Gilman (2008) found no significant difference in TSS strength when pulled in multiple directions. Staked and guyed trees were oriented with two stakes/ anchors near the winch and one stake/anchor on the opposite side of the tree such that the pull was in line with the opposing stake/anchor. Root ball anchored trees were oriented with the horizontal cross braces perpendicular to the plane of pull.

Once the pulling apparatus was installed on the tree, the winch was used to steadily increase cable tension until the target force [690 $\mathrm{N}^{*} \mathrm{~m}$ - the maximum bending moment recorded during the $25 \mathrm{~m} / \mathrm{s}(55 \mathrm{mph})$ wind load experiment] was observed on the dynamometer. At that point, the winch was released, the cable was removed from the tree, and trunk orientation was measured. In the short-term experiment, trees were pulled a second time with increasing force until either the tree or TSS failed; maximum force was then recorded. In the long-term TSS experiment, TSS components were removed prior to pulling. To avoid soil disturbance, stakes and guy anchors were not removed from the ground; only straps and guylines were removed. The horizontal cross braces were removed from the root ball anchored trees. Four successive pulling loads were then applied to each tree to generate progressively greater bending moments $(690,1651,3305$, and 4832 $\mathrm{N}^{*} \mathrm{~m}$ ). Between each successive pull, the winch was released and trunk orientation was measured. After the final pull, the root ball was winched from the ground to permit root evaluation.

\section{Tree Growth Measurements}

Before pulling the long-term trees, tree height, trunk orientation, trunk caliper, and trunk taper were remeasured. Current season shoot elongation was also measured on four randomly selected first-order branches. Three soil cores $[10 \mathrm{~cm}$ wide $x$ $15 \mathrm{~cm}$ deep ( 4 in $\times 6$ in)] were extracted from the backfill soil equidistant around the root ball of each tree. Roots were handsorted from the cores, digitally scanned, and analyzed with WinRHIZO PRO digital image analysis software (Regent Instruments, Inc., Quebec, Canada). Roots were then oven dried and weighed. After pulling the root balls of long-term trees from the ground, a count was taken of broken roots $\geq 2 \mathrm{~mm}$ diameter that were visibly extending from the backfill soil opposite the applied load. In cases where a large root with many smaller rootlets had broken, the individual rootlets were counted.

\section{Data Analysis}

In the short-term experiment, one-way analysis of variance (ANOVA) was used to analyze the fixed effects of TSS treatments on tree stability and component failure force. In the long-term experiment, one-way ANOVA was used to analyze the fixed effect of TSS treatments on tree stability and growth. When the treatment main effect was significant for a dependent variable, multiple comparisons were made between treatment groups using Tukey's HSD test $(\alpha=0.05)$.

\section{RESULTS}

\section{Short-Term TSS Experiment}

Under ambient site conditions [maximum recorded wind gust of $12 \mathrm{~m} / \mathrm{s}(27 \mathrm{mph})$ ], no TSS affected tree stability during the five weeks after planting (Table 2). Average change in trunk orientation was $\leq 2^{\circ}$ across treatment groups. The greatest change observed in a single tree (a root ball anchored tree) was $10^{\circ}$, which was barely perceptible without a measuring device. When the trees were winched, there were no differences in tree stability among the TSS types, all of which marginally improved stability relative to controls (Table 2). The mean change in trunk orientation was much greater in controls; however, high variance obscured statistical differences from stabilized trees.

Guyed trees endured significantly greater force before failure than both staked and root ball anchored trees, for which force was statistically similar (Table 2). For two-thirds of guyed trees, the initial component failure was the single anchor opposite the direction of the applied load. Similarly, in all staked trees the initial component failure was the opposite side stake. In the majority of cases, guy anchors and stakes broke at or near the soil line. Root ball anchoring systems typically failed when the horizontal cross brace on the opposite side of the pull direction separated from one or both vertical soil anchors.

\section{Long-Term TSS Experiment}

No TSS affected tree height growth, shoot elongation, root diameter, root length, or root mass seven months after planting (Table 3 ). Staked trees increased in trunk caliper significantly less than guyed or root ball anchored trees, but similar to control trees. The taper of staked trees decreased during the growing season, which was marginally different from guyed trees, for which trunk taper increased.

Under ambient site conditions [maximum recorded wind gust of $17 \mathrm{~m} / \mathrm{s}(38 \mathrm{mph})$ ], trees with and without TSS did not differ in their stability during the seven months after planting (Table 
Table 2. Stability of field-grown, balled and burlapped white ash (Fraxinus americana L. 'Autumn Purple') fitted with three stabilization systems $(n=6)$. Five-week pull tests conducted with systems installed. Seven-month pull tests conducted after systems removed. Standard error of mean shown in parentheses.

\begin{tabular}{|c|c|c|c|c|c|c|c|}
\hline \multirow[b]{2}{*}{ Treatment } & \multicolumn{3}{|c|}{ Five weeks after planting } & \multicolumn{4}{|c|}{ Seven months after planting } \\
\hline & $\begin{array}{l}\Delta \text { Trunk } \\
\text { orientation } \\
\text { ambient }^{\mathrm{z}}\left({ }^{\circ}\right)\end{array}$ & $\begin{array}{l}\Delta \text { Trunk } \\
\text { orientation } \\
690 \mathrm{~N}^{*} \mathrm{~m}^{\mathrm{y}}\left({ }^{\circ}\right)\end{array}$ & $\begin{array}{l}\text { System failure } \\
\text { force }(\mathrm{N})\end{array}$ & $\begin{array}{l}\Delta \text { Trunk } \\
\text { orientation } \\
\text { ambient }^{\mathrm{x}}\left({ }^{\circ}\right)\end{array}$ & $\begin{array}{l}\Delta \text { Trunk } \\
\text { orientation } \\
1651 \mathrm{~N}^{*} \mathrm{~m}\left({ }^{\circ}\right)\end{array}$ & $\begin{array}{l}\Delta \text { Trunk } \\
\text { orientation } \\
3305 \mathrm{~N}^{*} \mathrm{~m}\left(^{\circ}\right)\end{array}$ & $\begin{array}{l}\Delta \text { Trunk } \\
\text { orientation } \\
4832 \mathrm{~N}^{*} \mathrm{~m}\left({ }^{\circ}\right)\end{array}$ \\
\hline Control & $2(0.3) \mathrm{a}^{\mathrm{w}}$ & $16(22.4) \mathrm{a}$ & N/A & $2(0.3) \mathrm{a}^{\mathrm{x}}$ & $5(0.9) \mathrm{a}$ & $10(2.1) \mathrm{a}$ & $18(2.6) \mathrm{a}^{\mathrm{x}}$ \\
\hline Staking & $2(0.3) \mathrm{a}$ & $1(0.8) \mathrm{a}$ & $675(86) b$ & $2(0.5) \mathrm{a}$ & $6(1.6) \mathrm{a}$ & $15(5.8) \mathrm{a}$ & $19(4.7) \mathrm{a}$ \\
\hline Guying & $1(0.3) \mathrm{a}$ & $1(0.8) \mathrm{a}$ & $1675(520) \mathrm{a}$ & $1(0.2) \mathrm{a}$ & $5(0.8) \mathrm{a}$ & $9(0.9) \mathrm{a}$ & $11(1.4) \mathrm{a}$ \\
\hline Root ball anchoring & $1(0.4) \mathrm{a}$ & $2(2.9) \mathrm{a}$ & $942(260) b$ & $2(0.5) \mathrm{a}$ & $6(0.9) \mathrm{a}$ & $12(1.5) \mathrm{a}$ & $22(4.6) \mathrm{a}$ \\
\hline$P$-value & 0.2133 & 0.0727 & 0.0004 & 0.8052 & 0.8907 & 0.5462 & 0.2292 \\
\hline
\end{tabular}

${ }^{\mathrm{z}}$ Maximum recorded wind gust of $12 \mathrm{~m} / \mathrm{s}(27 \mathrm{mph})$.

${ }^{\mathrm{y}}$ Bending moments describe pulling force used to simulate destabilization.

${ }^{x}$ Maximum recorded wind gust of $17 \mathrm{~m} / \mathrm{s}(38 \mathrm{mph})$.

"Values followed by different letters are significantly different using Tukey's HSD test $(\alpha=0.05)$

Table 3. Growth and development of field-grown, balled and burlapped white ash (Fraxinus americana L. 'Autumn Purple') fitted with three stabilization systems for seven months after planting $(n=6)$. Standard error of mean shown in parentheses.

\begin{tabular}{|c|c|c|c|c|c|c|c|}
\hline Treatment & $\begin{array}{l}\text { Shoot elongation } \\
(\mathrm{cm})\end{array}$ & $\begin{array}{c}\Delta \text { Trunk caliper } \\
(\mathrm{mm})\end{array}$ & $\begin{array}{c}\Delta \text { Trunk taper } \\
(\mathrm{mm} / \mathrm{m})\end{array}$ & $\begin{array}{c}\text { Root dry mass } \\
\left(\mathrm{g} / \mathrm{m}^{3} \text { soil }\right)\end{array}$ & $\begin{array}{l}\text { Root length } \\
\text { (m/m3 soil) }\end{array}$ & $\begin{array}{l}\text { Root diameter } \\
(\mathrm{mm})\end{array}$ & $\begin{array}{c}\text { Broken roots }{ }^{2} \\
\text { (count) }\end{array}$ \\
\hline Control & $32.7(5.6) \mathrm{a}^{\mathrm{y}}$ & $1.6(0.4) \mathrm{ab}$ & $0.9(0.4) \mathrm{ab}$ & $468(74) \mathrm{a}$ & 6166 (767) a & $0.52(0.03) \mathrm{a}$ & $18(2) \mathrm{a}$ \\
\hline Staking & $32.6(4.3) \mathrm{a}$ & $0.7(0.3) b$ & $-0.3(0.3) b$ & $600(114) a$ & $5726(962) \mathrm{a}$ & $0.52(0.03) \mathrm{a}$ & 17 (3) a \\
\hline Guying & $29.9(2.7) \mathrm{a}$ & $2.5(0.2) \mathrm{a}$ & $2.1(0.7) \mathrm{a}$ & $677(85) \mathrm{a}$ & 6491 (1247) a & $0.55(0.03) \mathrm{a}$ & 17 (3) a \\
\hline Root ball anchoring & $37.2(7.1) \mathrm{a}$ & $1.9(0.3) \mathrm{a}$ & $0.9(0.7) a b$ & 914 (184) a & $7102(835) \mathrm{a}$ & $0.55(0.02) \mathrm{a}$ & 19 (3) a \\
\hline$P$-value & 0.7978 & 0.0037 & 0.0629 & 0.1161 & 0.7796 & 0.8979 & 0.8920 \\
\hline
\end{tabular}

${ }^{2}$ Roots $\geq 2 \mathrm{~mm}$ diameter extending from backfill soil in the root ball void after trees were pulled to failure.

${ }^{y}$ Values followed by different letters are significantly different using Tukey's HSD test $(\alpha=0.05)$

2 ). The mean change in trunk orientation was $\leq 2^{\circ}$ across treatment groups. The greatest change observed in a single tree (a control tree) was $4^{\circ}$, which was visually imperceptible. With the TSS components removed, trees were increasingly destabilized by progressively greater bending moments; however, there were no differences in tree stability among treatment groups (Table 2). When pulled to failure, trees failed by either trunk breakage or root ball lifting. Two-thirds of staked and nonstabilized trees failed by trunk breakage, whereas only one-third of root ball anchored trees failed in this manner. Trunk breakage and root ball lifting were equally common in guyed trees. TSS treatment had no effect on the number of broken roots observed in the backfill soil of the root ball void following tree failure (Table 3).

\section{TSS Cost and Durability}

There were no significant differences in the average installation time of TSS (data not shown). It took a two-person team 5-6 minutes to install all TSS types. At USD \$7.03, staking hardware was more than twice as expensive as guying (\$3.31) or root ball anchoring (\$3.00) hardware. The majority of the cost were wood components. Staking hardware was also considerably more bulky, which may have practical implications when planting numerous trees on a site.

After one growing season, all staking and guying systems remained intact. All stakes and guy anchors remained upright and firm in the ground. However, all staking straps and guylines had loosened since installation. Half of the staked trees and all the guyed trees had at least one strap that was visibly slack. All root ball anchoring systems also remained intact. However, the screws on the horizontal cross braces had loosened on about half the trees and could be removed from the vertical anchors when pulled forcefully by hand. No girdling or trunk abrasion from staking straps or guylines was observed on any of the trees.

\section{DISCUSSION}

Predicting the site and tree conditions that necessitate TSS use is a persistent challenge. Indeed, many landscapers will proactively install a TSS to avoid a potentially costly follow-up visit to reposition or replace a destabilized tree. In this study, nonstabilized ash trees remained upright for the duration of both the 5-week and 7-month studies despite occasionally substantial wind gusts. Appleton and Beatty (2004) observed no differences in the trunk orientation of stabilized and nonstabilized Bradford pears one year after installation despite a category two hurricane passing through the area six months after planting. The canopies of the ash trees in our study were noticeably thin, which is inherent to the species and typical of trees in transplant shock. As such, the wind-induced bending moment on these trees was likely considerably less than trees with denser canopies. In addition, the considerable weight of the soil root balls would have helped stabilize the trees, which would not be the case with container-grown or bare-root trees.

The stability of neither stabilized nor nonstabilized ash trees was adversely affected by winching to simulate a strong wind (equivalent to $25 \mathrm{~m} / \mathrm{s}$ ). This result did not support our hypothesis that nonstabilized trees would be more prone to wind throw. Given the 5-week interval between planting and pulling, new roots on control trees may have extended into backfill soil, improving their stability. Arnold and Struve (1989) observed rela- 
tively rapid root regeneration in bare-root, one-year-old green ash (Fraxinus pennsylvanica Marsh.). In their study, intact roots resumed growth seven to 20 days after transplanting, followed by adventitious root development from callus collars of pruned roots 10 to 19 days later. Although no root regeneration measurements were taken in the study addressed in this paper, very few adventitious roots were observed on the surface of root balls as they were pulled from the soil. A more likely explanation is that the bending moment imposed on the trees was too small to cause destabilization. As mentioned, the canopies were relatively thin, presumably reducing bending moments observed in the wind load test, which provided the analytical basis for the pull test. Had a species of similar nursery stock size, but denser canopy been evaluated, the results may have been much different. More research is needed to evaluate the stability of species differing in canopy density and crown architecture.

Although $90 \%$ of all experimental ash trees ( 22 of 24 ) had trunk orientation change less than $10^{\circ}$ after the 5 -week pull test, it should be noted that two control trees were significantly destabilized $\left(35^{\circ}\right.$ and $53^{\circ}$ ). Subsequent inspection of these trees revealed that roots within the root ball were very sparse and asymmetrically distributed. This finding reiterates the importance of inspecting the root system of nursery stock to determine the need for stabilization. Based on the overall performance of the nonstabilized trees under both ambient and simulated wind conditions, stabilization may not be required for similar trees planted on moderately windy sites.

TSS did not substantially inhibit ash tree growth or development during the first growing season after planting. After seven months, root growth into backfill soil was similar in stabilized and nonstabilized trees. Other researchers have found negative impacts of stabilization on root development (Jacobs 1954; Fayle 1976; Mayhead and Jenkins 1992), but trees in their studies were stabilized for much longer durations. There was a slight trend towards decreased trunk caliper growth and taper development in our staked ash trees relative to other treatment groups. Numerous past studies have observed negative effects of stabilization on trunk caliper growth and taper development (Harris and Hamilton 1969; Holbrook and Putz 1989; Svihra et al. 1999), but their stabilization systems were typically more rigid and installed longer than in the study detailed in this paper. The straps on staked trees were consistently tauter than those on guyed trees at the end of our study, which could have contributed to growth inhibition. An experiment of longer duration might have revealed more significant effects of staking on caliper growth and taper development. For landscape trees of similar size and structure, there should be little concern about detrimental effects of TSS on tree growth and development during the first growing season. Importantly, this is the recommended service life for a TSS in most landscape applications.

When TSS components were removed at the end of the first growing season, stabilized and nonstabilized ash trees were equally resilient when pulled, which contradicts previous work (Wrigley and Smith 1978; Whalley 1982). Both of these studies, however, tested different degrees and durations of immobilization. Soil moisture levels and soil composition may also have affected results. Here, both nonstabilized and previously stabilized trees remained upright until unrealistically large loads (more than twice the bending moment generated by a $25 \mathrm{~m} / \mathrm{s}$ wind) were applied. This outcome was expected because substantial root growth into backfill soil had occurred in both stabilized and nonstabilized trees during the first grow- ing season. Based on this study's results, TSS could be safely removed from small-caliper, field-grown ash trees after one growing season without concern for subsequent wind throw.

In this study, TSS differed in the maximum force they endured before component failure. The guying system withstood forces 1.7 to 2.5 times greater than the root ball anchoring and staking systems, respectively. Eckstein and Gilman (2008) observed similar TSS performance patterns; guying and root ball anchoring systems were the top performers whereas trees with a 2-stake system were no more robust than nonstabilized trees. These findings were expected since the greater attachment height of the guylines should reduce the overturning moment imposed by the winch. Although the three systems here were equally effective in stabilizing ash trees against a moderate force, there may be circumstances that require a more robust system. For example, vandals, who can exert more stress on small trees than even severe winds, often break landscape trees in urban areas. Where vandalism is a concern, guying systems, which were found to be the most robust, may be used. However, there is some concern that aboveground stabilization systems may increase the likelihood of vandalism and belowground systems may actually be a better choice. The results of this study and of Eckstein and Gilman (2008) suggest that a root ball anchoring system constructed of wooden stakes and cross braces performs very well in stabilizing both field and container grown trees. This belowground system may be preferred in locations where aboveground systems are undesirable due to space constraints or concerns for tripping hazards and aesthetics.

It is important to note that the wind loads experienced by the trees driven in the pickup truck are not perfectly equivalent to the winch-induced loads applied to the experimental trees. The pulling tests applied a constant, unidirectional, static force, unlike the complex, dynamic forces induced by wind. Therefore, the results of pulling tests should be interpreted with caution. TSS may perform differently under natural wind stress. However, the static forces of tree pulling are representative of the stress that vandals exert on a tree (Smiley et al. 2003).

\section{CONCLUSIONS}

This study evaluated three conventional tree stabilization systems under ambient and wind-simulating conditions. The systems performed equally well and even nonstabilized, medium-caliper, field-grown ash trees were tolerant of moderate to heavy wind loads. Similar trees should not require stabilization in the landscape unless extreme wind or vandalism is an issue. However, more research is needed to evaluate the stability of trees differing in nursery stock type, canopy density, and crown architecture before making unequivocal recommendations. The effect of soil moisture levels, soil composition, and fertilization on tree stability also needs to be evaluated. TSS components were very durable during the first growing season and did not substantially impact tree growth or cause trunk injuries. If TSS are removed after the first growing season, there should be limited concern for growth impacts or injuries. The guying system outperformed the other systems at extreme loads, indicating that this system may be preferable where vandalism or very strong winds are a concern. The root ball anchoring system should be a good alternative when aboveground systems are undesirable due to space constraints or concerns for tripping hazards, vandalism, or aesthetics. Although the three systems had similar installation times, the staking system components were twice as expensive and 
more bulky, which may be a practical consideration. Arborists can expect reliable performance from any of these three conventional systems; however, one system may be preferable depending on tree type, site constraints, or aesthetic expectations.

\section{LITERATURE CITED}

Appleton, B.L., and C.M. Beatty. 2004. Tree stabilization at installation. Proceedings of the Southern Nursery Association Research Conference, Section 9-Landscape 49:437-440.

Appleton, B.L., C.M. Cannella, P.E. Wiseman, and A.A. Alvey. 2008. Tree stabilization: current products and practices. Arboriculture and Urban Forestry 34(1):54-58.

Arnold, M.A., and D.K. Struve. 1989. Green ash establishment following transplant. Journal of the American Society for Horticultural Science 114(4):591-595.

Eckstein, R., and E.F. Gilman. 2008. Evaluation of landscape tree stabilization systems. Arboriculture and Urban Forestry 34(4):216-221.

Fayle, D.C.F. 1976. Notes: stem sway affects ring width and compression wood formation in exposed root bases. Forest Science 22(2):193-194.

Foster, R.S., and J. Blaine. 1978. Urban tree survival: trees in the sidewalk. Journal of Arboriculture 4:14-17.

Harris, R.W. 1984. Effects of pruning and staking on landscape trees. Journal of Environmental Horticulture 2(4):140-142.

Harris, R.W., and W.D. Hamilton. 1969. Staking and pruning young Myoporum laetum trees. Journal of the American Society for Horticultural Science 94(4):359-361.

Holbrook, N.M., and F.E. Putz. 1989. Influence of neighbors on tree form: effects of lateral shade and prevention of sway on the allometry of Liquidambar styraciflua (sweet gum). American Journal of Botany 76(12):1740-1749.

Jacobs, R.M. 1954. The effects of wind sway on the form and development of Pinus radiata. Australian Journal of Botany 2:33-51.

Kane, B., M. Pavlis, J. Seiler, and J.R. Harris. 2008. Crown configuration and stress in shade trees. Canadian Journal of Forest Research 38:1275-1289.

Leiser, A.T., and J.D. Kemper. 1968. A theoretical analysis of a critical height of staking landscape trees. Proceedings of the American Society for Horticultural Science 92:713-720.

Leiser, A.T., and J.D. Kemper. 1973. Analysis of stress distribution in sapling tree trunk. Journal of the American Society for Horticultural Science 98:164-170.

Mayhead, G.J., and T.A.R. Jenkins. 1992. Growth of young Sitka spruce (Picea sitchensis (Bong.) Carr.) and the effect of simulated browsing, staking and tree shelters. Forestry 65(4):453-462.

Neel, P.L. 1967. Factors influencing trunk development of landscape trees. Proceedings of the International Shade Tree Conference 43:293-303
Patch, D. 1987. Trouble at the stake, pp 77-84. In D. Patch (Ed.). Advances in Practical Arboriculture. Forestry Commission Bulletin 65. HMSO, London, England.

Peltola, H., S. Kellomaki, A. Hassinen, and M. Granander. 2000. Mechanical stability of Scots pine, Norway spruce and birch: an analysis of tree-pulling experiments in Finland. Forest Ecology and Management 135:143-153.

Smiley, E.T., and B. Kane. 2006. The effects of pruning type on wind loading of Acer rubrum. Arboriculture and Urban Forestry 32(1):33-40.

Smiley, E.T., E. LeBrun, and E. Gilbert. 2003. Evaluation of extraction force for wooden guy anchors. Journal of Arboriculture 29(5):295297

Svihra, P., D. Burger, and D. Ellis. 1999. Effects of 3 trunk support systems on growth of young Pyrus calleryana trees. Journal of Arboriculture 25(6):319-324.

Whalley, D. 1982. Lighter the better-tree staking. Gardener's Chronicle and Horticultural Trade Journal 191(24):23-24.

Wrigley, M.P., and G.S. Smith. 1978. Staking and pruning effects on trunk and root development of four ornamental trees. New Zealand Journal of Experimental Agriculture 6(4):309-311.

Acknowledgments. This study was funded in part by a grant from the Mid-Atlantic Chapter of the International Society of Arboriculture. Additional support was provided by Virginia Tech's Departments of Forestry and Horticulture. We acknowledge John Homyk, John James, Michael Pavlis, Donnie Sowers, and Stephanie Worthington for assistance with experiment installation and data collection. We also extend gratitude to the Bartlett Tree Experts Research Lab for use of the tree sled for experimentation.

Alexis A. Alvey

Cornell Cooperative Extension of Suffolk County

423 Griffing Avenue, Suite 100

Riverhead, NY 11901, U.S.

P. Eric Wiseman (corresponding author)

Department of Forestry

Cheatham Hall

Virginia Tech University

Blacksburg, VA 24061, U.S.

pwiseman@vt.edu

Brian Kane

Department of Natural Resources Conservation

Holdsworth Hall

University of Massachusetts - Amherst

Amherst, MA 01003, U.S. 
Résumé. Nous avons évalué en champs trois systèmes conventionnels de stabilisation (par tuteurage, par haubanage au sol, par ancrage des mottes) sur des frênes d'Amérique (Fraxinus americana L. 'Autumn Purple') de 6,4 cm de calibre mis en motte. Cinq semaines et sept mois après leur plantation, la performance du système de stabilisation a été évaluée sous des conditions ambiantes de vent et sous des conditions de simulation de vent au moyen d'une traction artificielle. Les frênes non stabilisés demeuraient verticaux lors des deux périodes de l'étude en dépit de rafales de vents substantielles. Lors des tests de traction, l'étude a permis de déterminer que les systèmes de stabilisation performaient tous bien et que même les arbres non stabilisés étaient tolérants à des pressions par des vents modérés ou forts. Les systèmes de stabilisation différaient selon la force maximale qu'ils peuvent supporter avant qu'une composante se brise. Le système de haubans supportait respectivement des forces de 1,7 à 2,5 fois plus élevées que celui par ancrage de la motte ou par tuteurage. Les composantes des systèmes de stabilisation étaient très durables lors de la première saison de croissance et ne causaient pas d'impacts substantiels sur la croissance en hauteur, l'élongation des pousses, la croissance en diamètre ou en longueur des racines ou encore sur la masse de racines, et ce sept mois après la plantation. Après une saison de croissance, les arbres, stabilisés ou non, demeuraient verticaux à moins que des charges irréalistes soient appliquées. Les implications pratiques pour la gestion des arbres ornementaux sont discutées.

Zusammenfassung. Wir bewerteten drei konventionelle Baumverankerungssysteme (Pfahl, Erdanker, Wurzelballenverankerung) an im Freiland gezogenen, ballierten Weißeschen mit 6,4 cm Stammdurchmesser. Nach fünf Wochen und nach sieben Monaten nach der Pflanzung wurden die Stabilisierungssysteme unter normalen und simulierten Windbedingungen getestet. Die nicht-stabilisierten Bäume blieben nach fünf Wochen und sieben Monaten trotz gelegentlicher Starkwinde aufrecht. Nach den Zugtests schnitten alle Stabilisierungssysteme gut ab und auch die freistehenden Bäume waren gegenüber schweren Windlasten tolerant. Die Stabilisierungssysteme differierten bei der maximalen Windlast, bevor sie versagten. Die Erdankersysteme hielten 1,7 bis 2,5 mal größere Windlasten aus als die Wurzelballenverankerungen und die Baumpfähle. Die Komponenten der Stabilisierungssysteme waren in der ersten Saison sehr haltbar und hatten nach sieben Monaten keinen besonderen Einfluss auf das Höhenwachstum, Trieblänge, Wurzeldurchmesser, -länge, oder -masse. Nach einer Wachstumssaison blieben freistehende und vorher stabilisierte Bäume solange aufrecht, bis sie einer unrealistischen Windlast ausgesetzt wurden. Die praktischen Auswirkungen auf den Landschaftsbau werden diskutiert.

Resumen. Se evaluaron tres sistemas convencionales de estabilización de árboles (tutoreo con estacas, cables y anclaje de la bola de raíces) en fresnos blancos (Fraxinus americana L. 'Autumn Purple') crecidos en terreno, de $6.4 \mathrm{~cm}$ ( $2.5 \mathrm{pulg})$ de calibre, con bola en arpillera. El comportamiento de los sistemas de estabilización fue evaluado a las cinco semanas y a los siete meses después de la plantación, bajo condiciones ambientales de viento como también con pruebas de simulación del mismo. Los fresnos no estabilizados permanecieron de pie durante los estudios tanto de las cinco semanas como de los siete meses, a pesar de ocasionales ráfagas de viento. Después de las pruebas, el estudio encontró que los sistemas de estabilización trabajaron igualmente bien y que aun los árboles no estabilizados fueron tolerantes a las cargas de viento de moderadas a fuertes. Los sistemas de estabilización difirieron en la fuerza máxima que soportaron antes de fallar. El sistema de cables aguantó fuerzas de 1.7 a 2.5 veces más que los sistemas de anclaje y de estacas, respectivamente. Siete meses después de la plantación los componentes de los sistemas de estabilización fueron muy duraderos durante la primera estación de crecimiento y no impactaron sustancialmente el crecimiento de la altura del árbol, elongación de brotes, diámetro de las raíces, longitud o masa de raíces. Después de una estación de crecimiento, los árboles no estabilizados, como los estabilizados previamente permanecieron derechos hasta que una carga anormal fue aplicada. Se discuten las implicaciones prácticas para el manejo de los árboles en el paisaje. 